\title{
GENE DIVERSITY IN GREVILLEA POPULATIONS INTRODUCED IN BRAZIL AND ITS IMPLICATION ON MANAGEMENT OF GENETIC RESOURCES ${ }^{1}$
}

\author{
Valderês Aparecida de Sousa ${ }^{2 *}$, Antonio Nascim Kalil Filho², Emerson Gonçalves Martins ${ }^{2}$,Jarbas Yukio \\ Shimizu ${ }^{2}$ and Fernando Albertin ${ }^{2}$. \\ ${ }^{1}$ Received on 18.08.2017 accepted for publication on 26.04.2018. \\ ${ }^{2}$ Empresa Brasileira de Pesquisa Agropecuária, Centro Nacional de Pesquisa de Floresta, Colombo, PR-Brasil. E-mail: \\ <valderes.sousa@embrapa.br>,<antonio.kalil@embrapa.br>,<e.martins49@yahoo.com.br>,<shimizujy@gmail.com>and \\ $<$ feralbertin@gmail.com>. \\ *Corresponding author.
}

\begin{abstract}
We describe isoenzymes variability in six populations of Grevillea robusta from a provenances and progenies test established in a randomized block design with five plants per replication in Southern Brazil. The population genetic structure was examined by using biochemical markers in 5-year old trees, specifically at $M D H-3, P G M-2, D I A-2, P O-1, P O-2, S O D-1$, and $S K D H-1$ loci. The northern provenances (Rathdowney and Woodenbong) showed a strong divergence in relation to the average of provenances when alleles per locus $(A p)$, allele richness $(R s)$, Nei's gene diversity $(H)$, and inbreeding coefficient $(f)$ were considered. Inbreeding in varying degrees was detected. The commercial control showed the highest inbreeding coefficient, $(f=0.4448)$, whereas the provenance average was $f=0.2306$, possibly due to insufficient sampling of populations in their origin (Australia). Despite its restricted natural range, a positive correlation between genetic divergence and geographic distance among original populations was detected. Genetic distance and cluster analyses based on the Bayesian model revealed three distinct provenance groups: 1) Rathdowney-QLD and Woodenbong-QLD; 2) Paddy's Flat-NSW; and 3) Mann River-NSW, Boyd River-NSW and the commercial control (material used in Brazil). The grouping of the control to both Mann River-NSW and Boyd River-NSW provenances suggests that the northern provenances have the highest potential for genetic improvement of wood productivity in Brazil, due to their high genetic diversity and low inbreeding coefficient.
\end{abstract}

Keywords: Isoenzymes, Provenances/progenies trial, Tree breeding

\section{DIVERSIDADE GENÉTICA EM POPULAÇÕES DE GREVÍLEA INTRODUZIDAS NO BRASIL E SUA IMPLICAÇÃO NO MANEJO DE RECURSOS GENÉTICOS.}

\begin{abstract}
RESUMO - A variabilidade isoenzimática para seis populações de Grevillea robusta, oriundas de um teste de procedências/progenies, implantado no delineamento em blocos casualizados com 5 plantas por parcela, no Sul do Brasil, é descrita. A estrutura genética da população foi analisada utilizando-se marcadores bioquímicos, aos 5 anos de idade, especificamente para os locos MDH-3, PGM-2, DIA-2, PO-1, PO-2, SOD-1, e SKDH-1. As procedências do norte de ocorrência natural (Rathdowney e Woodenbong) apresentaram divergência genética superior, em relação à média das progênies, considerando o número de alelos por locus, (Ap), a riqueza alélica (Rs), a diversidade genética de Nei (H), e o coeficiente de endogamia (f). A endogamia foi detectada em diversos graus. A testemunha comercial apresentou o maior coeficiente de endogamia, ( $\mathrm{f}=0,4448$ ), comparativamente à média das procedências $(\mathrm{f}=0,2306)$, possivelmente devido à insuficiente amostragem populacional na região de origem (Austrália). Apesar de sua ocorrência natural restrita, observou-se correlação positiva entre divergência genética e distância geográfica entre as populações originais. A distância genética e análise de cluster, baseada no modelo bayesiano, mostrou três grupos de procedências distintos: 1) RathdowneyQLD e Woodenbong-QLD; 2) Paddy's Flat-NSW; e 3) Mann River-NSW, Boyd River-NSW e a testemunha comercial (material utilizado no Brasil). O agrupamento da testemunha com as procedências Mann River-NSW e Boyd River-NSW sugere um maior potencial das procedencias do norte para o melhoramento genético visando à produção de madeira no Brasil, devido a sua elevada diversidade genética e baixo coeficiente de endogamia.
\end{abstract}

Palavras-Chave: Isoenzimas; Testes de procedências/progênies; Melhoramento florestal. 


\section{INTRODUCTION}

Grevillea (Grevillea robusta A. Cunn.) is a tree species of Proteaceae family occurring naturally in Queensland, Australia, in areas extending from northern Gympie (latitude $25^{\circ} 50^{\prime} \mathrm{S}$ ) to Guy Fawkes and Orara river areas $\left(30^{\circ} 10^{\prime} \mathrm{S}\right)$. Orara River is a tributary of Clarence River that runs mostly through New South Wales at altitudes varying from sea level to 1,100 $\mathrm{m}$ at Bunya Mountains in Queensland (Harwood et al., 1997). This species occurs in two main habitats: in narrow bands associated with Eucalyptus along Richmond and Clarence rivers, and mixed with Araucaria cunninghamii Aiton ex. Don forests (Webb, 1959).

Grevillea populations are geographically discontinuous and separated by Sclerophyllous forests that are prone to fire, or by climax forests where they struggle to survive forest fires and the disadvantage of their typically small population size (Harwood et al., 1997). In general, there is a small number of effectively reproducing individuals. In Emu Creek, Queensland ( $\left.28^{\circ} 58^{\prime} \mathrm{S} ; 152^{\circ} 10^{\prime} \mathrm{E}\right)$ for example, only 90 trees were breeding in an elongated population stretching 2.4 $\mathrm{km}$ next to a stream. Population density of less than one individual per hectare is observed in association with Araucaria cunninghamii forests (Webb et al., 1967). Also, according to a survey by Harwood (1992), grevillea is naturally distributed in a number of small populations distant two to $10 \mathrm{~km}$ apart. This situation leads to genetic structures with strong differentiation among and weak within populations (Moran and Hoper, 1983, 1992).

Natural grevillea stands have been continuously depleted through exploitation for wood (Maiden, 1911) and deforestation for agricultural and pasture lands since the early days of the European colonization. Remnant populations are represented by young dispersed trees in degraded sites as well as in areas where Araucaria forests were removed for agriculture practice.

Grevillea has been introduced into many countries in South America, Africa and South Asia, especially for shade trees in tea and coffee plantations. It is also an important source of firewood and timber in small upland farms in tropical regions of eastern and central Africa (Harwood, 1989). It was first brought to Brazil in the late $19^{\text {th }}$ Century (Instituto Brasileiro do Café,
1981) and disseminated throughout the southern and southeastern regions where climatic conditions are favorable for the species. Other uses of grevillea in Brazil include wood production for timber (Iwakiri et al., 2004), and as windbreak around croplands and pasture (Baggio, 1983; Durigan and Simões, 1987; Campanha et al., 2007) as well as in urban forestry (Beloto and De Angelis, 2003; Kramer and Krupek, 2012). According to Ribaski (2006), grevillea plays an important role in agroforestry systems. It contributes to improve environmental conditions in the field and provide comfort to animals and better pasture development. Moreover, it produces valuable logs for processing by small landowners (Radomski and Ribaski, 2011). Grevillea is known not to compete for resources with agricultural crops, while maintaining fast growth even in low fertility soils (Pinto Júnior et al., 2013) and is one of most popular tree species planted in pasture lands in Brazil (Almeida, 2011).

Efforts in genetic improvement of grevillea in Brazil started with provenance/progeny tests in the early 1980's. Important variations among provenances were reported by Shimizu et al. (1998) and Martins et al. (2000). Thereafter new provenances were reintroduced in Brazil and institutions as Instituto Florestal de São Paulo (IF-SP), Embrapa Florestas (CNPF) and Instituto Agronômico do Paraná (IAPAR) which demonstrated it potential Paraná, São Paulo and Mato Grosso do Sul States. Differences between them have been reported (Sebbenn et al., 1999; Martins and Neves, 2003; Martins and Neves, 2004; Martins et al., 2004; Martins et al., 2005; Martins et al., 2006; Leal and Ramos, 2011).

Population genetics studies are important elements in supporting genetic improvement and conservation programs, especially in the case of grevillea. These are vital in understanding the genetic structure in the remnant populations in Australia as well as in populations introduced into different countries. Studies have revealed high outcrossing rates (0.92; Hadwood et al., 1990) and evidence of self-incompatible breeding system in natural populations (Hadwood, 1992) and also in Kenya (Kalinganire et al., 1996, 2000).

So far, no study on population genetics had been carried out in grevillea populations introduced into Brazil. The present work addresses this issue in order to generate elements in support to the species breeding and conservation programs.

Revista Árvore. 2018;42(2):e420205 


\section{MATERIALAND METHODS}

\subsection{Populations and sampling}

The study was based on a five-year old combined provenance and progeny trial involving Australian sources (Table 1) and a control from commercial populations disseminated in Brazil, presumably of NWS origin. The trial was established in Ponta Grossa, State of Paraná, Brazil (latitude $25^{\circ} 05^{\prime} 42^{\prime \prime} \mathrm{S}$, longitude $50^{\circ}$ 09' 43" W, and elevation $900 \mathrm{~m}$ above sea level). The local climate is classified according Koeppen's system as $\mathrm{Cfb}$ (mild summers). Average summer temperatures remain below $22^{\circ} \mathrm{C}$ and winters are mild, although severe frosts can sometimes occur. Annual rainfall exceeds 1,500 $\mathrm{mm}$ and no soil water deficit is observed. The local soil is classified as Cambissol (equivalent to Inceptisol) and the relief varies from flat to a slightly rolling topography.

The trial was established in a randomized blocks design with seven replications of 5-plant plots. The treatments were represented by five Australian provenances and one local commercial control of unknown original provenance (Table 1).

Natural populations were sampled in areas extending from latitudes $28^{\circ} 13^{\prime} 00^{\prime \prime S}$ to $29^{\circ} 5300^{\prime \prime S}$, longitudes $152^{\circ} 26^{\prime} 00^{\prime \prime} \mathrm{E}$ to $152^{\circ} 52^{\prime} 01^{\prime \prime E}$, and altitudes $15 \mathrm{~m}$ to 100 $\mathrm{m}$ above sea level. The maximum distance (based on Ersts, 2017) among sampled populations was 171.21 $\mathrm{km}$ between Rathdowney and Boyd River, and the minimum distance of $25.08 \mathrm{~km}$ between Rathdowney and Woodenbong.

\subsection{Isoenzyme electrophoresis}

Isoenzyme technique played an important hole in characterizing plants, in general, and also forest species studies since the years 1970 have been largely replaced by molecular techniques, they are still informative and maintain their applicability, especially in studies of population genetics. Nowadays articles using isoenzymes as main technique (Litkowiec et al., 2013; Mathiasen and Premoli, 2013; Harter et al.; 2015; Medoukali et al., 2015; Chlumský et al., 2016; Kutlunina et al., 2016; Luo et al., 2016; El-Esawi et al., 2017; Konzen and Martins, 2017) as well in association with molecular markers (Streiff et al., 1998; De Woody et al., 2009; Ekart et al., 2016; Reichmann et al., 2017; Quipildor et al., 2018;) are still published worldwide on population genetic studies. Although molecular markers are more informative and currently used, in some cases isozymes is still helpful to screen population and individuals

Table 1 - Geographic coordinates of natural Grevillea robusta populations included in the study.

Tabela 1 - Coordenadas geográficas das populações naturais de Grevillea robusta incluídas no estudo.

\begin{tabular}{|c|c|c|c|c|}
\hline Population & Longitude(E) & Latitude(S) & Altitude(m) & Tree number(n) \\
\hline 1. Rathdowney-QLD & $28^{\circ} 13^{\prime} 00^{\prime \prime}$ & $152^{\circ} 52^{\prime} 01^{\prime \prime}$ & 100 & 83 \\
\hline 2. Woodenbong-NSW & $28^{\circ} 26^{\prime} 00^{\prime \prime}$ & $152^{\circ} 45^{\prime} 00^{\prime \prime}$ & 200 & 72 \\
\hline 3 Paddy's Flat-NSW & $28^{\circ} 44^{\prime} 00^{\prime \prime}$ & $152^{\circ} 26^{\prime} 00^{\prime \prime}$ & 180 & 80 \\
\hline 4 Mann River-NSW & $29^{\circ} 24^{\prime} 00^{\prime \prime}$ & $152^{\circ} 29^{\prime} 00^{\prime \prime}$ & 60 & 79 \\
\hline 5 Boyd River-NSW & $29^{\circ} 53^{\prime} 00^{\prime \prime}$ & $152^{\circ} 27^{\prime} 00^{\prime \prime}$ & 15 & 74 \\
\hline \multicolumn{3}{|c|}{ 6. Commercial control-Brazil (ex-NSW) } & 85 & \\
\hline
\end{tabular}

Table 2 - Genetic parameters based on isozyme loci in Grevillea robusta provenances.

Tabela 2 - Parâmetros genéticos de procedências de Grevillea robusta baseados em locus isoenzimáticos.

\begin{tabular}{|c|c|c|c|c|c|c|c|c|}
\hline \multirow[t]{2}{*}{ Population } & \multirow[b]{2}{*}{$n$} & \multirow{2}{*}{$A p$} & \multirow[b]{2}{*}{$R s$} & \multirow{2}{*}{$\mathrm{He}$} & & \multirow[b]{2}{*}{$H$} & \multirow[b]{2}{*}{$f$} & \multirow[b]{2}{*}{$F_{S T}$} \\
\hline & & & & & & & & \\
\hline 1. Rathdowney & 83 & 3.14 & 3.02 & 0.5338 & 0.3497 & 0.5350 & 0.3465 & 0.0434 \\
\hline 2. Woodenbong & 72 & 3.00 & 2.88 & 0.5441 & 0.4374 & 0.5449 & 0.1973 & 0.0695 \\
\hline 3. Paddy's Flat & 80 & 2.86 & 2.84 & 0.5317 & 0.4573 & 0.5319 & 0.1414 & 0.0781 \\
\hline 4. Mann River & 79 & 2.86 & 2.67 & 0.5022 & 0.4576 & 0.5023 & 0.0896 & 0.0708 \\
\hline 5. Boyd River & 74 & 2.86 & 2.77 & 0.4870 & 0.4052 & 0.4876 & 0.1688 & 0.0644 \\
\hline $\begin{array}{l}\text { 6. Commercial } \\
\text { control * }\end{array}$ & 85 & 2.86 & 2.85 & 0.4849 & 0.2699 & 0.4861 & 0.4448 & 0.0583 \\
\hline Overall mean & & 2.93 & & 0.5140 & 0.3962 & & 0.2306 & 0.0641 \\
\hline
\end{tabular}

Genetic material previously introduced into Brazil; $\mathrm{n}=$ sample size, $A p=$ average number of alleles per locus; $R s=$ allele richness per locus and per sample; $H_{e}=$ expected heterozygosity; $H_{e},=$ observed heterozygosity; $H=$ genetic diversity $($ Nei, 1987$) ; f=$ inbreeding coefficient; $F_{S T}=$ fixation index (Wright, 1965). 
generating results to support decisions on genetic improvement and conservation.

Fresh leaves were labeled and stored at $-30{ }^{\circ} \mathrm{C}$ until enzyme extraction. They were homogenized in an extraction buffer with germanium dioxide (Mitton et al., 1979). Electrophoresis was conducted using lithium-borate buffer 8.3 (Scandalios, 1969) for peroxidase (PO) and diaphorase (DIA) in a constant $60 \mathrm{~mA}$ system for four hour; histidine 8.0 (Brown et al., 1975), malate dehydrogenase $\mathrm{MDH}$ ), and phosphoglucomutase (PGM) in a constant $50 \mathrm{~mA}$ for five hours; and tris-citrate 8.6 (Fowler and Morris, 1977), superoxide dismutase (SOD), and shikimate dehydrogenase (SKDH) in 60 $\mathrm{mA}$ for five hours.

\subsection{Descriptive statistics and clustering}

Allele frequencies, number of alleles per locus $(A)$, expected heterozigosity $\left(H_{e}\right)$, and observed heterozigosity $\left(H_{o}\right)$ were estimated through GDA (Lewis and Zaykin, 2001) software. Allele richness (Rs), both per locus and per sample (Petit et al., 1998), unbiased gene diversity $(H)(\mathrm{Nei}, 1987)$, fixation index $\left(F_{S T}\right)$, inbreeding coefficient $\left(f\right.$ or $\left.F_{I S}\right)$, and geographic distance (Ersts, 2017) were also estimated in this study. Hamilton's (1971) relatedness was calculated by using FSTAT program, version 2.9.3.2. (Goudet, 2002). Divergence among populations was inferred by plotting estimates of pairwise differences (Rousset's distance (1997) and geographic distance (Ersts, 2017).

Genetic structure of populations was performed by using Admixture analysis using Bayesian assignment procedures (Structure 2.2.3 (Pritchard et al., 2000) using 500.000 burn-in periods and Evanno method (Evanno, 2005) implemented by Earl (2012), a website program, for estimating $\mathrm{K}$ partitions (population groups).

Tree plot of Nei's genetic distance was perfomed using NTSYSpc Version 2.10 z (Rohlf, 2002).

\section{RESULTS}

\subsection{Genetic diversity}

Genetic diversity parameters obtained from isoenzymes analysis are summarized in Table 2 . Measures of genetic variation within populations (Table 2) indicated an average of 2.93 alleles per locus (Ap) across loci. Rathdowney and Woodenbong populations showed higher numbers of alleles per locus (3.14 and 3.00, respectively) than the average of other populations $(A p=2.86)$. These provenances are geographically closer than the distances between other provenances.

The expected heterozygosity $\left(H_{e}\right)$ varied from 0.4849 to 0.5441 with an average of 0.5140 . They were higher from those reported by Harwood et al. (1997) varying from 0.080 to 0.131 ) using isoenzymes. Heterozygous deficiency was observed in all populations. Woodenbong $\left(H_{o}=0.3497\right.$ against $\left.H_{e}=0.5338\right)$ and the commercial control $\left(H_{o}=0.2699\right.$ against $\left.H_{e}=0.4849\right)$ were the most outstanding in that respect. The highest inbreeding coefficients were observed in Rathdowney and the commercial control ( 0.3465 and 0.4448 , respectively) when compared to other provenances (average of 0.2314 ).

Private alleles (number four) were found both in the commercial control at locus $M H D 3$ and in Rathdowney at locus $P O 1$, suggesting that the local population contains other than the Australian northernmost provenances.

By comparing Rathdowney, the northernmost provenance, with Woodenbong the southernmost provenance, it becomes evident that they represent two distinct groups, as reported by Harwood et al. (1997). The local commercial control showed a high inbreeding level. Therefore, in spite of their common presence in small farms in Brazil, they must be used with caution, due to inbreeding depression.

\subsection{Genetic structure and variation among populations}

Two most distinct groups are shown in Figure 1 by using Nei's (1978) genetic distance. The first includes populations from the northern region of the species range (Rathdowney and Woodenbong); the second is formed by all other Australian provenances. Within the second group, Paddy's Flat differs from Mann River and Boyd River. Also, a clear difference was observed between the second group and the commercial control. In general the grouping of provenances followed a pattern close to their geographical distribution. This evidence is confirmed in Figure 2. There was an indication of a close association (Rousset's distance) between the population variation and their geographic distances $\left(r^{2}=0.8316\right)$.

Revista Árvore. 2018;42(2):e420205 

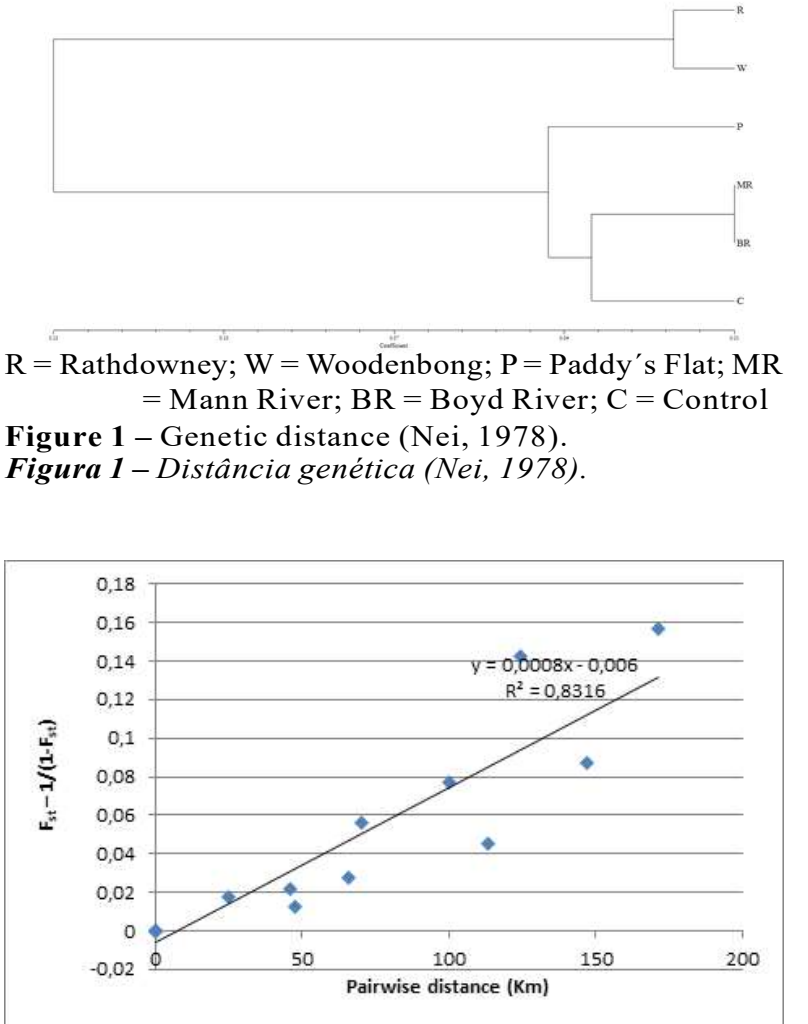

Figure 2 - Differentiation among populations considering the pattern of variation in Rousset's distance $\left(F_{S T} /\right.$ $\left.1-F_{S T}\right)$ ) in relation to geographic distances of grevillea populations. $\mathrm{R}^{2}=0.83, \mathrm{P}<0.0001 *$.

Figura 2 -Diferenciação entre as populações considerando o padrão de variação da distância de Rousset $\left(\left(F_{S T)}\right.\right.$ $\left.1-F_{S T}\right)$ ) em relação às distâncias geográficas das populações de grevílea. $R^{2}=0,83, P<0.0001$ *

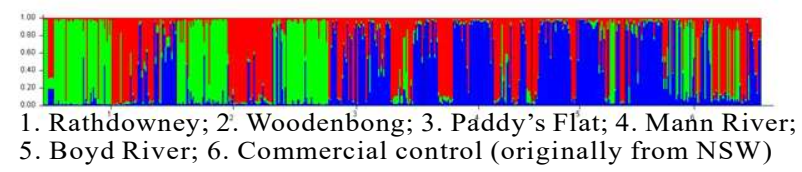

Figure 3 - Baysian model- based clustering analysis (2000). Figura 3-Análise de cluster baseado no modelo de análise

\subsection{Admixture analysis} Bayesiana (Pritchard et al., 2000).

Three groups were shown by $\mathrm{K}$ value. These groups are represented in the admixture analysis (Figure 3 ). Populations from the northern distribution range (Rathdowney, Woodenbong and Paddy's Flat) showed similar mixture patterns. Within the group including Mann River and Boyd River also similar admixture patterns were observed. The commercial control showed a high degree of admixture, in similar pattern to that observed for the southern provenances.

\section{DISCUSSION}

The present study demonstrated clear variations among provenances. Also, correlation of provenance variation with their populations' geographic distribution became clear. The evidence of a high inbreeding rate and other aspects in variation patterns in the local commercial control raises concerns about continued use of this material. The main issue seems to be the restricted genetic variation in this material because of the small number of trees initially sampled for introduction into Brazil (Shimizu et al., 1998). This fact, over the years, has promoted damaging effects caused by inbreeding, such as the reduction of germination rate and loss of vigor and malformation of planted trees (Ferreira and Martins, 1998). This explains the higher inbreeding coefficient observed for ancient Grevillea germplasm introduction (in the mid-19th century) in relation to new populations introduced after 1990 (late 20th century).

For this reason, Embrapa Forest, in partnership with CSIRO, from Australia, introduced a new Australian germplasm base considering a better sampling including more provenances and individuals within provenances. This material were established as several trials and has been showing a higher potential for wood production, with genetic gains from $23 \%$ to $33 \%$ compared to original (commercial) introduced material (Martins et al., 2003, 2004).

Although apparently seed production in Brazil is normal, from 70,000 to 110,000 seeds per $\mathrm{kg}$ (Lamprecht, 1990) an accurate study about seed production is lacking. A high seed production in regions close to Curitiba city has been observed (Kalil Filho, personal communication) however information on literature were not found. Seed production among others depends on mating system and pollinators. Grevillea robusta is known as an outcrossing species not only in the natural occurrence region (Harwood et al., 1992) but also in introduced areas, as Kenya (Kalinganire et al., 2000) because of its protandrous (Brough, 1933) and self-incompatible (Hadwood, 1992; Kalinganire et al., 1996; Kalinganire et al., 2000) characteristics. Moreover it is pollinated by birds and bats (Jøker, 2000; Kalinganire et al., 2001)) not by insects (Brough, 1933; Kalinganire

Revista Árvore. 2018;42(2):e420205 
et al., 2001). It was still observed by Kalinganire et al., (2001) a non-efficient seed production derivate from absence of a higher pollinator activity in Kenya. Thus a desirable seed production depends not only from environmental suitability to produce flowers but also from adequate and abundant pollinators to reach a higher seed production. In absence of specific pollinators in adequate amounts seed production can be increased through controlled pollination. Kalinganire et al. (2001) has observed experimentally, in Kenya, that controlled pollination produced more seeds than open pollination. Therefore in Brazil we have to be aware about pollinators issue and in some cases to consider controlled pollination as a tool to increase seed production aiming the advance in grevillea breeding programs.

Data from a provenance tests carried out in northern State of Paraná and elsewhere in Brazil (Sebbenn et al., 1999; Martins et al., 2006; Leal and Ramos, 2011) have demonstrated higher performances of recently introduced provenances in comparison to previously introduced material.

The pioneer work on population genetics in grevillea as described by Harwood et al. (1997) offered the basic elements to establish genetically sound breeding programs for a more efficient use and conservation of this valuable species. The multitude of knowledge that is being gradually amassed on the species breeding system, geographic variation, genetic parameters, silvicultural requirements, wood quality, and its role in agroforestry systems is a key to a better use and efficient conservation measures for this species.

\section{CONCLUSIONS}

The information gathered on different aspects of population genetics in grevillea introduced into Brazil represents an asset of vital importance for the best use of this forest resource. Pioneer introductions made in the early $20^{\text {th }}$ century raised interest in this species for its value as shade tree and wind break around agricultural crops. However, low wood production and bad stem form discouraged any other form of utilization. Genetic studies have demonstrated that undesirable performances were basically due to inbreeding depression because of a very narrow genetic base.

Further introductions of well sampled populations from the northern areas of the species range are seen as means to place this species in focus as a multiple use alternative, especially in small farms. If ample genetic variation is preserved, there will always be opportunities for genetic improvement toward different end uses and suited for production in different ecologic sites.

\section{ACKNOWLEDGMENT}

We thank to Mrs. Simone Aparecida Sopchaki the valuable collaboration in populations' genotyping.

\section{REFERENCES}

Almeida RG. Uso de eucalipto em sistemas de integração lavoura-pecuária-floresta. Revista DBO. [acessado: 28 de jun. 2011]. http:// www.portaldbo.com.br/Portal/Artigos/Uso-deeucalipto-em-sistemas-de-integracao-lavourapecuaria-floresta/712.

Baggio AJ. Sistema Agroflorestal grevílea x café: início de uma nova era na agricultura paranaense? Embrapa-URPFCS; 1983. 16p. (Circular Técnica, 9)

Beloto GE, De Angelis BLD. “Arborização urbana e sua relação com o uso do solo na cidade de Maringá, Estado do Paraná" Acta Scientiarum Technology. 2008;25(1):103-11.

Brough P. The life history of Grevillea robusta (A. Cunn). Proceedings of Linnean Society of New South Wales. 1933;58:33-73.

Brown, ADH, Matheson AC, Eldridge KG Estimation of the mating system of Eucalyptus obliqua L. Hérit by using alozyme polymorphisms. Australian Journal of Botany, 1975; 23: 931-949.

Campanha MM, Santos RHS, Freitas GBD, Martinez HEP, Jaramillo-Botero C, Garcia SL, Análise comparativa das características da serrapilheira e do solo em cafezais (Coffea arabica L.) cultivados em sistema agroflorestal e em monocultura, na Zona da Mata, MG. Revista Árvore. 2007;31(5):805-12.

Chlumský J, Koutecký P, Plaèková I, Štech M. Is genetic diversity congruent with morphological diversity across the distributional range of the Melampyrum subalpinum group

(Orobanchaceae)?. Flora-Morphology, Distribution, Functional Ecology of Plants, 220, pp.74-83, 2016.

Revista Árvore. 2018;42(2):e420205 
De Woody J, Rickman TH, Jones BE, Hipkins VD. Allozyme and microsatellite data reveal small clone size and high genetic diversity in aspen in the southern Cascade Mountains. Forest Ecology and Management. 2009;258(5):687-96.

Durigan G, Simões JW. Quebra-ventos de Grevillea robusta A. Cunn. - Efeitos sobre a velocidade do vento, umidade do solo e produção do café. IPEF-Instituto de Pesquisas e Estudos Florestais. 1987;36:27-34.

Earl DA, von Holdt BM. .Structure harvester: a website and program for visualizing Structure output and implementing the Evanno method. Conservation Genetics Resources. 2012;4(2):359-61.

Ekart AK, Semerikova SA, Semerikov VL, Larionova AY, Kravchenko AN, Dymshakova OS. Variability of allozyme and cpSSR markers in the populations of Siberian spruce. Russian Journal of Genetics. 2016;52(3):273-80.

El-Esawi MA, Mustafa AEZ, Badr S, Sammour R. Isozyme analysis of genetic variability and population structure of Lactuca L. germplasm. Biochemical Systematics and Ecology. 2017;70:73-9.

Ersts PJ. Geographic distance matrix generator(version 1.2.3). American Museum of Natural History, Center for Biodiversity and Conservation. 2017. Available from ttp:// biodiversityinformatics.amnh.org/open_source/ gdmg. [accessed on: 2017-5-25].

Evanno G, Regnaut S, Goudet J. Detecting the number of clusters of individuals using the software STRUCTURE: a simulation study. Molecular Ecology. 2005;14(8):2611-20.

Ferreira CA, Martins EG. O potencial da grevílea (Grevilea robusta A. Cunn.) para reflorestamento. In: Galvão APM. coordenador. Espécies não tradicionais para plantios com finalidades produtivas e ambientais. Colombo: Embrapa Florestas; 1998. p.171-8.

Fowler DP, Morris RW. Genetic diversity in red pine; evidence for low heterozygosity. Canadian Journal of Forestry Research. 1977; 7: 343-7.

Goudet J. FSTAT (Version 1.2): a computer program to calculate F statistics. Journal of
Heredity. 2002;86:485-6. (Version 2.9.3.2). Available at: http://www2.unil.ch/popgen/softwares/ fstat.htm.

Hamilton WD. Selection of selfish and altruistic behavior in some extreme models. In: Eisenberg JF, Dillon WS. editors. Man and beast:

Comparative social behavior. Washington, DC: Smithsonian Institute Press; 1971. p.57-91.

Harter DE, Nagy L, Backhaus S, Beierkuhnlein C, Fussi B, Huber G. et al. A comparison of genetic diversity and phenotypic plasticity among European beech (Fagus sylvatica L.) populations from Bulgaria and Germany under drought and temperature manipulation. International Journal of Plant Sciences. 2015;176(3):232-44.

Harwood CE. 'Grevillea robusta - An Annotated Bibliography.’ Nairobi: ICRAF; 1989.

Harwood CE. Natural distribution and ecology of Grevillea robusta In: Harwood CE. editor. Grevillea robusta in agroforestry and forestry. Nairobi: ICRAF; 1992. p.21-8.

Harwood CE; Bell JC; Moran, GF. Isozyme studies on genetic variation and the breeding system in Grevillea robusta. I : Agroforestry and Forestry. Nairobi: International Centre for Research in Agroforestry, 1992; p.165-176.

Harwood CE, Moran GF, Bell C. Genetic differentiation in natural populations of Grevillea robusta. Australian Journal of Botany. 1997;45(4):669-78.

Instituto Brasileiro do Café. Cultura de café no Brasil. Rio de Janeiro: 1981.

Iwakiri S, Shimizu J, Silva JDC, Menezzi CHSD, Puehringher CA, Venson I. et al. Produção de painéis de madeira aglomerada de Grevillea robusta A. Cunn. ex R. Br. Revista Árvore. 2004;28(6):883-7.

Jøker D. Grevillia robusta. Seed Leaflet, (15). Copenhagen: University of Copenhagen/Danida Forest Seed Centre; 2000.

Kalinganire A, Harwood CE, Simons AJ, Moncur MW, Slee M. Reproductive ecology of Grevillea robusta in western Kenya. In: Tree Improvement 
for Sustainable Tropical Forestry. QFRI-IUFRO Conference 27 Oct 1 Nov. 1996 Caloundra. Gympie: Queensland Forest Research Institute; 1996. p.238-43.

Kalinganire A, Harwood CE, Slee MU, Simons AJ. Floral structure, stigma receptivity and pollen viability in relation to protandry and selfincompatibility in silky oak (Grevillea robusta A. Cunn.). Annals of Botany. 2000;86:133-48.

Kalinganire A, Harwood CE, Slee MU, Simons AJ. Pollination and fruit set of Grevillea robusta in western Kenya. Austral Ecology. 2001;26(6):637-48.

Konzen ER, Martins MP. Contrasting levels of genetic diversity among populations of the endangered tropical palm Euterpe edulis Martius. Cerne. 2017;23(1):31-42.

Kramer JÁ, Krupek RA. Caracterização florística e ecológica da arborização de praças públicas do município de Guarapuava. Revista Árvore. 2012;36(4):647-58.

Kutlunina NA, Belyaev AY, Knyazev MS. The structure of genotypic diversity and the possibility of sexual reproduction in populations of Tulipa riparia (Liliaceae). Russian Journal of Ecology. 2016;47(4):412-8.

Lamprecht H. Silvicultura nos trópicos. Eschoborn: GTZ; 1990. p.296-7.

Leal AC, Ramos ALM. Desempenho de cinco procedências de Grevillea robusta no norte do Paraná. Floresta. 2011;4(2):287-94.

Lewis PO, Zaykin D. Genetic Data Analysis: Computer program for the analysis of allelic 2001 [internet]. Version $1.0(\mathrm{~d} 16 \mathrm{c})$. Free program distributed by the authors over the internet from http://lewis.eeb.uconn.edu/lewishome/ software.html, 2001.

Litkowiec M, Plitta BP, Lewandowski A. Importance of genetic variation for conservation of English yew genetic resources in Europe. Sylwan. 2013;157(10):754-60.

Luo N, Yu X, Nie G, Liu J, Jiang Y. Specific peroxidases differentiate Brachypodium distachyon accessions and are associated with drought tolerance traits. Annals of Botany. 2016;118(2):259-70.

Maiden JH. The forest flora of the New South Wales. Sidney: Government Printer; 1911. v.1

Maòka P, Kormu ák A, Galgóci M, Gömöry D. Genetic status of the putative hybrid swarms of mountain dwarf pine and Scots pine in contact zones of their distribution in Slovakia. Biologia. 2015;70 (10):1318-25.

Martins EG, Shimizu JY, Ferreira CA. Desempenho de procedências de grevílea em Quedas do Iguaçú, PR. Boletim de Pesquisa Florestal. 2000(40):45-56.

Martins EG, Neves EJM, Sturion JA, Duleba N. Volume de madeira e ganho genético de progênies de grevílea (Grevillea robusta Cunn.) de segunda geração na região de Londrina, Paraná. Boletim de Pesquisa Florestal. 2005(51):45-55.

Martins EG, Neves E, Martins K. Desempenho de progênies de segunda geração de grevílea nos municípios de Avaré, SP, e Londrina, PR.

Colombo: Embrapa Florestas; 2006. (Embrapa Florestas. Comunicado técnico, 170).

Martins EG, Sturion JA, Neves EJM. Produtividade de madeira e ganho genético de procedências de grevílea (Grevillea robusta Cunn.) na região de Ponta Grossa, Paraná. Boletim de Pesquisa Florestal. 2004(48):29-40.

Martins EG, Neves E. Grevillea robusta Cunn.: resultados obtidos com procedências no Estado do Paraná e São Paulo. Colombo: Embrapa Florestas; 2003. (Comunicado técnico, 103).

Martins EG, Neves EJM. Grevillea robusta (Cunn.): sementes melhoradas para usos múltiplos. Colombo: Embrapa Florestas; 2004. (Comunicado técnico, 126)

Martins EG, Neves EJM, Shimizu JY, Ferreira CA. Avaliação e ganho genético estimado para o volume de procedências de Grevilea em três diferentes locais. Boletim de Pesquisa Florestal. 2003(46):3-20.

Mathiasen P, Premoli AC. Fine-scale genetic structure of Nothofagus pumilio (lenga) at

Revista Árvore. 2018;42(2):e420205 
contrasting elevations of the altitudinal gradient. Genetica. 2013;141(1-3):95-105.

Medoukali I, Bellil I, Khelifi D. Morphological and Isozyme variation in natural populations of the Genus Notulae. Botanicae Horti Agrobotanici Cluj-Napoca. 2015;43(1):86.

Mitton JB, Linhart YB, Sturgeon KB, Hamrick JL. Allozyme polimorphisms detected in mature needle tissue of ponderosa pine. Journal Heredity. 1979;70:86-9.

Moran GF, Hoper SD. Conservation of the genetic resources of rare and widespread eucalypts in remnant vegetation. In: Saunders DA, Arnold GW, Burbidge A, Angas JM. editors. 'Nature conservation: the nature remnants of native vegetation". Sidney: Surrey Beatty/CSIRO and the Department of Conservation and Land Management: 1992. p.151-62

Moran GF, Hopper SD. Genetic diversity and the insular population structure of the rare granite species Eucalyptus caesia Benth. Australian Journal of Botany. 1983;31:161-2.

Nei M. Molecular evolutionary genetics. New York: Columbia University Press; 1987.

Nei M. Estimation of average heterozygosity and genetic distance from a small number of individuals. Genetics. 1978;89(3):583-90.

Petit RJ, El Mousadik A, Pons O. Identifying populations for conservation on the basis of genetic markers. Conservation Biology. 1998;12:844-55.

Pinto Júnior JE, Santos PET, Aguiar AV, Kalil Filho AN, Paludzyszyn Filho E, Sturion JÁ et al. Melhoramento genético de espécies arbóreas na Embrapa Florestas: uma visão histórica, Colombo: Embrapa Florestas; 2013. (Documentos, 259)

Pritchard JK, Stephens M, Donnelly P. Inference of population structure using multilocus genotype data. Genetics. 2000;155:945-59 (Program STRUCTURE Version 2.3.3).

Quipildor VB, Kitzberger T, Ortega Baes P, Quiroga MP, Premoli AC. Regional climate oscillations and local topography shape genetic polymorphisms and distribution of the giant columnar cactus Echinopsis terscheckii in drylands of the tropical Andes. Journal of Biogeography. 2018;45(1):116-26.

Radomski MI, Ribaski J. Produção de grevílea e eucalipto em sistema silvipastoril na região do Arenito de Caiuá, noroeste do Paraná. Colombo: Embrapa Florestas; 2011. (Documentos, 231)

Reichmann MC, Zanella CÂ, Valério Júnior C, Borges ACP, Sausen TL, Paroul N et al., 2017. Genetic diversity in populations of Maytenus dasyclada (Celastraceae) in forest reserves and unprotected Araucaria forest remnants. Acta Botanica Brasilica. 2017;31(1):93-101.

Ribaski J. Sistemas agroflorestales pecuarios: algunas experiencias desarrolladas en Brasil. In: Annales do $4^{\circ}$ Congreso Latinoamericano de Agroforestería para la Producción Agropecuaria Sostenible. 2006. p.48.

Rohlf FJ. NTSYS-pc: numerical taxonomy system ver. 2.1. Setauket, NY: Exeter Publishing; 2002.

Rousset F. Genetic differentiation and estimation of gene flow from F-statistics under isolation by distance. Genetics. 1997;145(4):1219-28.

Scandalios JG. Genetic control of multiple molecular forms of enzymes in plants: a review. Biochemical Genetics. 1969;3(1):37-79.

Sebbenn AM, Durigan G, Siqueira ACMF, Pontinha AAS. Teste de procedências de Grevillea robusta A. Cunn. Revista do Instituto Florestal. 1999;11:65-73.

Shimizu JY, Martins EG, Ferreira CA. Avaliação inicial de procedências de grevílea no noroeste do Paraná. Boletim de Pesquisa Florestal. 1998;37:4154.

Sousa VA, Richards CM. Genetic diversity and biogeographic determinants of population structure in Araucaria angustifolia Bert. O Ktze. In: $1^{\text {st }}$. Workshop of Embrapa'S Scientists in USA, 2011, Fort Collins. $1^{\text {st }}$. Workshop of Embrapa' $S$ Scientists in USA. Washington: Labex; 2011. p.37.

Sousa VA, Valgas RA, Lavoranti OJ, Chaves Neto A; Shimizu JY. Genetic differentiation among

Revista Árvore. 2018;42(2):e420205 
Araucaria populations in Brazil. In: Anales do $13^{\text {a }}$ Congreso Forestal Mundial, Desarrollo forestal: equilibrio vital. Buenos Aires: FAO; 2009.

Streiff R, Labbe T, Bacilieri R, Steinkellner H, Gloss1 J, Kremer A. Within-population genetic structure in Quercus robur L. and Quercus petraea (Matt.) Liebl. assessed with isoenzymes and microsatellites. Molecular Ecology. 1998;7(3):317-28.
Webb LJ. A physionomic classification of Australian rainforests. Journal of Ecology. 1959;47:551-602.

Webb LJ, Tracey JG, Haydock KP. A factor toxic to seedlings to the same species associated with living roots of the non-gregarious subtropical rainforest tree Grevillea robusta. Journal of Applied Biology. 1967;4:13-25.

Wright S. The interpretation of population structure by $F$-statistics with special regard to system of mating. Evolution. 1965;19:395-420.

Revista Árvore. 2018;42(2):e420205 